\title{
Renewable Energy Potential of Sewage in Zambia
}

\author{
Aubrey Simwambi1,2*, Francis Yamba ${ }^{1}$, Sophia Hibler ${ }^{2}$, Kabwe Mulenga ${ }^{3}$ (i) \\ ${ }^{1}$ Department of Mechanical Engineering, University of Zambia, Lusaka, Zambia \\ ${ }^{2}$ The Bremen Overseas Research and Development Association, Lusaka, Zambia \\ ${ }^{3}$ Red Spot Limited_4065, Kitwe, Zambia \\ Email: *aubrey.simwambi@gmail.com
}

How to cite this paper: Simwambi, A. Yamba, F., Hibler, S. and Mulenga, K. (2020) Renewable Energy Potential of Sewage in Zambia. Open Journal of Applied Sciences, $10,328-350$.

https://doi.org/10.4236/ojapps.2020.106025

Received: January 24, 2020

Accepted: June 27, 2020

Published: June 30, 2020

Copyright (C) 2020 by author(s) and Scientific Research Publishing Inc. This work is licensed under the Creative Commons Attribution International License (CC BY 4.0).

http://creativecommons.org/licenses/by/4.0/

\section{(c) (i) Open Access}

\begin{abstract}
This study was aimed at investigating the renewable energy potential of communal and municipal wastewater through methane production in biogas digesters and the use of the captured methane for energy production in biogas engines. It was conducted on biogas digesters receiving and pre-treating communal and municipal wastewater in the Zambian city of Livingstone. Wastewater inflow rates into biogas units including the wastewater turbidity, total dissolved solids (TDS), temperature, $\mathrm{pH}$, conductivity and Chemical Oxygen Demand (COD) were measured during the study. And all the produced biogas was measured and combusted on-site during the course of the research. In order to know the methane content of the gas, the $\mathrm{CO}_{2}$ content in the biogas was measured with a $\mathrm{CO}_{2}$ indicator. The study showed that the predominant factor affecting the process of methane production from wastewater to the greatest extent is the COD concentration of the inflowing wastewater and not the system hydraulic retention times (HRT's). The COD treatment levels of the tested systems ranged between 27 and 86 percent and the degree of breakdown primarily depended on the COD concentration of the influent wastewater. On renewable energy fuel production, about 3.54 kilograms of COD in each system produced a kilogram of methane. Communal wastewater was able to produce an average of 600 grams of methane per cubic meter of wastewater treated whilst municipal wastewater with less COD concentration was only able to produce about 64.5 grams of methane per cubic meter wastewater treated. With the use of a $45 \mathrm{kw}$ Cummins 6 BT biogas engine, the respective wastewaters had potential to produce about $2.6 \mathrm{kWh}$ and $0.1 \mathrm{kWh}$ of electric energy per cubic meter of wastewater treated at a levelized cost of USD 9 cents per kilowatt-hour. Temperature also showed that it has significant effect on methane production as a degree temperature rise in the anaerobic system increased the methane production mass rate by 1.2 percent.
\end{abstract}




\section{Keywords}

Biogas, Methane, Renewable, COD, Levelized

\section{Introduction}

In many parts of Africa, a significant number of people do not have access to electric energy and lack basic sanitation [1]. This is a result of high population growths coupled with increasing economic developments and increase high energy demands while lagging service infrastructure growth [2]. Zambia has about 40 percent of the population living in urban areas making it one of the most and fastest growing countries in Sub-Saharan Africa [3]. The high urbanization rates have resulted in low-income settlements known as Peri-urban areas. These areas account for the highest number of Zambia's population and form a major feature of the Country's urban landscape [4]. A study done by Mulenga reported of Peri-urban areas in Zambia having poorly developed infrastructure and most adversely affected by water-borne diseases due to the absence of basic sanitation infrastructure and services [5]. The upsurge in population, high urbanization rates, and economic development have resulted in increased human waste production and overloading current waste management systems [1]. In 2018, only about 63.3 percent of Zambia's population in urban areas had access to acceptable sanitation [6].

Improving access to sanitation is one of the most effective means to improve public health [7]. Wastewater from sewer connected areas in Zambia is predominantly treated using stabilization ponds as conventional wastewater treatment facilities implemented in the 1950s and '80s have become obsolete due to poor operations and maintenance [8]. Thus, financial requirements and huge space requirements make it challenging to provide conventional sanitation solutions in rapidly urbanizing areas in Zambia and other developing countries [9]. Inadequate sanitation access in the country often leads to deadly water-borne diseases such as cholera and typhoid, which results in thousands of infections and hundreds of deaths. In 2016, 1179 cholera cases claiming 31 fatalities were reported whilst between October 2017 and May 20185905 suspected cases claiming 98 deaths were recorded [10] [11]. The World Bank reported in 2012 that inadequate sanitation services negatively affect the health of many Zambians living in major cities, and its economic impact costs Zambia approximately USD 194 million every year [12].

Other stressors for Zambia's population and economy are the lapses in energy supply as only about 26 percent of Zambia's urban population and less than 5 percent of its rural population has access to electricity [13]. The energy costs have also been rising since 2015 due to increasing costs of production and the lowering of hydropower potential caused by poor rain patterns [14] [15]. Poor sanitation infrastructure and services together with low energy accessibility slows 
down economic growth and puts a significant number of Zambians at a disadvantage. The country has a very low per capita energy consumption of only about $700 \mathrm{kWh} /$ capita [16]. Industrialization and population growth demand a need for higher energy production as present sources of energy depletes [17]. Therefore, new approaches and in-depth research towards sanitation and energy are required for developing nations like Zambia. Process approaches that simultaneously tackle challenges of adequate sanitation and energy coverage are in particularly high demand [1] [18] [19]. One possible solution approach for wastewater treatment and energy fuel production could be the utilization of low-tech anaerobic biogas digesters so-called "in-situ digesters". The use of anaerobic digestion for wastewater sludge treatment is an applied technology with growing recognition in the area of sanitation [20]. Biogas digesters are specifically brought on hand in the anaerobic treatment of wastewater sludge due to a variety of benefits, such as the abatement of greenhouse gases, organic waste minimization and wastewater pathogen reduction [21]. In biogas digesters, organic solids in sewage are trapped and through microbial activities broken down leading to biogas production. The technology has been used for more than 1000 years to improve water quality and sanitation in many regions [22].

In-situ biogas digesters offer a broad realistic application in low-income countries as an alternative technological approach to conventional wastewater treatment plants as they are constructed with locally sourced materials and labor, and require no external energy input during operation. Various benefits have been previously reported on the implementation of "in-situ digesters": socio-economic, environmental, and health benefits at the household, community, and global level [23]. Additionally, if enabling market conditions could prevail, income from direct biogas sales, electricity generation or reduced expenses for the sewerage network operators through generation of their own energy for operations could further be relevant factors for the feasibility of digester implementation for sewage treatment and energy production. There is however little empirical information on the production of biogas from sewage in in-situ digesters for electricity production, in particular regarding a continuously flowing fresh human wastewater through biogas digester systems. Equally, economic implications of installing in-situ anaerobic treatment systems to yield the potential biogas from human sewage and produce energy in Africa are not available as the technology is considered undeveloped for the region [24].

Limited studies have been conducted in laboratory conditions on undiluted septic tank sludge with a focus on COD removal [7]. However, empirical knowledge on parameters affecting biogas production potential from sewage is limited and needs further clarification as only simulant faecal matter has been used in laboratory experiments [7]. The difficulty has been attributed to the complexity of setting up experimental facilities along with sewerage networks and the occupational health and safety complexity procedures of handling human excreta waste in research. The test results on undiluted human excreta in laboratory ex- 
periments have revealed that the amount of biogas that can be yielded from anaerobic systems batch fed with human wastewater sludge is limited, in comparison to batch fed livestock manure and other feedstock [25]. The American biogas council however reported in 2012 that the organic matter in raw municipal wastewater contains almost 10 times the energy required for its treatment and that some wastewater treatment plants (WWTPs) could produce $100 \%$ of the energy they need to operate. The council also reported that the energy generated at WWTPs could potentially meet over $10 \%$ of the national electricity demand of the United States [26]. This paper investigates the feasibility of electric energy production per cubic meter of communal and municipal wastewater in the Zambian city of Livingstone. The study was done through investigating the biogas production potential per cubic meter sewage and the use of the produced methane in biogas for electricity production in a biogas engine. It was done on communal sewage using biogas digesters purely treating communal sewage in a compound called Libuyu and on municipal sewage using digesters situated at the Dambwa North sewage ponds. The viability of renewable energy production from sewage was done by calculating the levelised cost of energy (LCOE) production from the implementation and operations of in-situ biogas units and a Cummins $6 \mathrm{BT}$ biogas engine of $45 \mathrm{~kW}$ power production capacity biogas units sized and cost based on the construction and operational costs of in-situ biogas digesters needed to produce methane for energy to run the pond station 24-hours a day. The methane production potential was based on the volume of sewage required to be anaerobically treated over a determined period in the digester system referred to as "hydraulic retention time (HRT)". The LCOE was then compared to the national energy regulated tariffs for power selling by the Zambia Electricity Supply Corporation (ZESCO). The study also looked at the influence of temperature on the methane production from the retained wastewater and its effects on other influencing parameters total and free ammonia in the wastewater.

\section{Methods and Materials}

\section{Study sites:}

1) Libuyu Compound (Sanitation up-grade, wastewater treatment and Renewable Energy)

The communal sewage study was conducted in Libuyu compound on the aspect that the compound has sewerage system with biogas units that receive wastewater predominantly coming from household sanitation facilities. Libuyu compound is a low-income settlement within the city of Livingstone, Zambia. Nine in-situ biogas digesters (two $10 \mathrm{~m}^{3}$, five $20 \mathrm{~m}^{3}$, one $30 \mathrm{~m}^{3}$ and one $40 \mathrm{~m}^{3}$ ) have been implemented along the compounds sewer network during its construction between 2008 and 2011. The biogas digesters serve as pre-treatment plants for communal wastewater in which particulate matter is trapped before conveyed to a pump station from which it is then pumped to wastewater stabili- 
zation ponds for further treatment before disposal into the Zambezi River. The digesters were installed to create a free solid sewer network for 267 households and concurrently produce biogas as a cooking energy fuel. Each digesters biogas is supplied to one household in proximity. Between March and September 2015 data on wastewater flow, COD outflow and biogas production was collected and analyzed (for COD content and the ratio of COD breakdown and biogas production) [27]. The collected data was used in this study for the process of understanding the relationship between communal wastewater treatment in biogas digesters and biogas production.

\section{Experimental Design for Libuyu}

\section{a) Hydraulic retention time and wastewater temperature}

Biogas digesters in Libuyu are located along the sewage networks and each digester positioned at a point where it receives wastewater from a specific area of the community, creates a solid free sewer network and joins the main sewer line conveying the sewer to the pump station. The study design in Libuyu focused on measuring the daily wastewater inflows, influent and effluent $\mathrm{pH}$ and temperature and the COD concentration of the effluent. The wastewater inflow rates measured by the wastewater filling rates into a 3-liter container (measured on a threefold during a test period between July and September of 2015) were used to calculate the HRT for each digester at a time as specific digester design volumes were known. The results were leveled to median values and based on this data, the HRT of each biogas digester was assumed constant for the study period as the number of households connected to each digester units remained unchanged. The temperature of the influent wastewater was measured hourly with the use of on-set data loggers (HOBOware UA-001-64) submerged in every digester inlet to know the anaerobic temperature of the system.

\section{b) Biogas production}

The biogas produced from each digester in the study was measured in 2015 across the warm wet and dry cold seasons spanning between March and August with the securely installed Elster Amco G4 200 diaphragm gas meters (Elster Group, Germany) and HOBO pulse data loggers (UX90-001, Onset Computer Corporation; Bourne, MA) connected to the meters. The data loggers were set to measure gas on an hourly basis during the 6-month study period. The assumption made during biogas measurements was that the biogas production equaled the rate of biogas consumption for each biogas plant and the connected household, therefore, only the biogas consumption was monitored daily. However, once monthly, full biogas production capacity for each system was measured through a controlled release of all biogas over 48-hour periods.

To ensure standard stabilized results of the obtained biogas production rates in 2015, biogas production rates from 7 biogas units and the biogas consumption rates of the connected households was measured for a second time in March 2019 using Elster Amco G4 200 diaphragm gas meters only connected to the biogas network before the biogas stove. Spring pressure gauges were also used 
during the measuring period to assist in the interpretation of the biogas volumes stored in domes. During this measuring period, the daily biogas consumption by the households, the consumed biogas was measured at 08:00, 14:00 and 20:00 o'clock in order to get morning, afternoon and evening consumption rates. The $\mathrm{CO}_{2}$ content in the biogas was measured for all gas metered biogas digesters (BGDs) every morning and evening during gas meter readings using a $\mathrm{CO}_{2}$ indicator (Brigon Messtechnik GmbH; Rodgau, Germany). To minimize biogas production errors due to the study setup and qualify the assumption in the 2015 study design, the biogas left out in the dome after the households had finished their daily cooking was completely burnt out in the night. The gas meters and pressure gauges connected to the network were monitored and recorded after the burn out in the early morning to know the gas produced in the night.

c) Wastewater treatment performance

The COD performance of the Libuyu biogas system was assessed with the use of COD inflow dataset provided by Laramee who measured it using standard Photometetric LCI 400 COD methods and the Hach Photometer Dr 2800 [27]. The total COD removed through methane production was calculated using a mass balance equation in Equation (1).

$$
\mathrm{COD}_{\text {out methane }}(\mathrm{mg} / \mathrm{L})=\frac{\mathrm{CH}_{4}(\mathrm{~g}) * f_{b g}}{Q}+\frac{\mathrm{CH}_{4}(\mathrm{l}) * f_{b g}}{Q}
$$

where $\mathrm{COD}_{\text {out methane }}$ is effluent $\mathrm{COD}(\mathrm{mg} / \mathrm{L}) ; Q$ is the Wastewater flow-rate ( $\mathrm{m}^{3} /$ day); $\mathrm{CH}_{4}$ (g) is $\mathrm{CH}_{4}$ released in the gas phase $\left(\mathrm{m}^{3} /\right.$ day); $\mathrm{CH}_{4}(\mathrm{l})$ is $\mathrm{CH}_{4}$ that remains dissolved in the liquid effluent ( $\mathrm{m}^{3} /$ day) [28]; [29] and $f_{b g}$ is the conversion factor of $\mathrm{CH}_{4}$ to COD adjusted for Livingstone. Soto et al., (1993) reported a factor $f_{b g}$ of $(1 / 385) \mathrm{gCOD} / \mathrm{ml}^{-} \mathrm{CH}_{4}$ at $20^{\circ} \mathrm{C}$ [30]. Using the Ideal Gas Law in Equation (2),

$$
\frac{P V}{T}=\frac{p v}{t}
$$

where $P, V$ and $T$ are pressure, volume and temperature conditions at point 1 and $p, v$ and $t$ are respective conditions at the site respectively; this led to a factor of $1 / 437 \mathrm{gCOD} / \mathrm{ml}^{-\mathrm{CH}_{4}}$ at 25 degrees celsius and a 920 meter elevation with site pressure calculated using the barometric formulae in Equation (3)

$$
P_{2}=P_{1} \mathrm{e}^{\frac{-m g h}{k T}}
$$

where $P_{2}$ and $P_{1}$ are pressure at the study site and sea level respectively, $m$ is the gas molar mass, $h$ is the height above sea level, $k$ is the gas constant and $T$ is the average temperature at the study site.

$\mathrm{CH}_{4}$ (g) production ( $\mathrm{m}^{3} /$ day) was computed using measured biogas production. The produced biogas was normalized into kilograms by the use of Equations (4) with relations between height, pressure, density and temperature.

$$
\frac{\rho_{2}}{\rho_{1}}=\frac{P_{2} \operatorname{Tr}}{P_{1} \operatorname{Tr}}=\mathrm{e}^{-\left(\frac{g}{R T}\right)\left(h_{2}-h_{1}\right)}
$$


where $\mathrm{g}$ is the gravitational acceleration at a certain altitude $\left(\mathrm{g}_{0}=9.81 \mathrm{~m} / \mathrm{s}^{2}\right)$ $\left(\mathrm{m} / \mathrm{s}^{2}\right) ; r$ is the earth radius $(6378 \mathrm{~km})(\mathrm{m}) ; h_{2}$ is the Height above the ground (Geometric height above sea level) $(\mathrm{m}) ; h_{1}$ is the height above the center of the earth $\left(h_{a}=h_{g}+r\right)(\mathrm{m}) ; p_{1,2}$ is the pressure $\left(\mathrm{Pa}=\mathrm{N} / \mathrm{m}^{2}\right)$ at point 1 and 2 respectively; $\rho_{1,2}$ is the density $\left(\mathrm{kg} / \mathrm{m}^{3}\right)$ at point 1 and 2 respectively; $T_{1,2}$ is the Temperature $(\mathrm{K})$ at point 1 and 2 respectively; $R$ is the gas constant $(287.05 \mathrm{~J} /(\mathrm{kgK}))$. At a temperature of $288.15 \mathrm{~K}$ at sea level, the atmospheric pressure is $1.01325 \times 105$ $\mathrm{N} / \mathrm{m}^{2}$ and the biogas density is ${ }^{*} 1.225 \mathrm{~kg} / \mathrm{m}^{3}$.

The density of methane in the biogas was calculated in proportion to the measured $\mathrm{CO}_{2}$ content in the gas phase only and the density was based on the density of methane at STP of $0.668 \mathrm{~kg} / \mathrm{m}^{3}$ and of $\mathrm{CO}_{2}$ of $1.842 \mathrm{~kg} / \mathrm{m}^{3}$. The density was then converted to the density of biogas in Livingstone according to Equation (4).

2) Dambwa Wastewater Stabilization Ponds (social- and urban-environment; wastewater origin)

Municipal wastewater was studied using primary data collected at the Dambwa North sewerage treatment plant, the main wastewater treatment plant of Livingstone. The City has an approximate population of 35,000 households [31]. Its economy is characterized by the tourism and hospitality industry and does not have chemical producing industries which could chemically contaminate wastewater. Therefore, wastewater received at the Dambwa treatment plants is predominantly domestic with some portion of wastewater coming from the hotel and catering industry.

Much of the City's wastewater is treated in wastewater stabilization ponds and some being managed on-site in areas with no sewer connections. The ponds at the study site ponds receive wastewater from the greater parts of the city of Livingstone, which has been documented by the municipal council to have 21 zoned areas of which 17 are peri-urban or low-income neighborhoods [32]. By March 2019, the utility company Southern Water and Sanitation Company Ltd (SWASCo) sewer connection records showed that only about 9509 households in the city were connected to the municipal sewer network which conveys the wastewater to the main wastewater stabilization ponds located on the southern outskirts of the city. Three pump stations are installed along the entire city's sewer network, namely the Libuyu, Linda and the Eureka pump station, which are equipped with Gorman Rupp T10A3-B pumps coupled to $22 \mathrm{kw}$ motors installed in topographically low areas of the conveyance network. The pumps operate either on electricity from the national utility company ZESCO (Zambia Electricity Supply Company) or from a diesel Generator set in times of power supply outage ("load shedding"). The equipment pumps wastewater at a rate of 129 liters per second. The pumps are controlled by float levels in sumps in order to increase pumping and power efficiency. Records of energy consumption rates at the Dambwa pump station were obtained together with pump specifications to know the daily amount of wastewater received and pumped into the sewerage ponds. 


\section{Experimental Design for Dambwa Digesters}

Data collection (procedures, materials/ instruments used)

a) Hydraulic retention time, Biogas production, temperature and carbon dioxide

The experimental design and study (conducted between April and October 2017) for the Dambwa digesters was aimed at establishing the best HRT for biogas production from municipal wastewater and obtain the optimum biogas production rates per cubic meter of treated wastewater. The design involved conveying some volume of wastewater running into the stabilization ponds into three $200 \mathrm{~m}^{3}$ digesters, adjusting wastewater flow rates and monitoring the biogas production rates. The water flow levels in the pond inlet manhole allowed for connections for free flow of sewage into the biogas units hence some sewage from the pump station was diverted and continuously fed into the biogas system. The wastewater inflow rates into the digesters were determined by measuring the wastewater flow into a standard 20-liter container. Six times measurements were taken at each flow adjustment and the result averaged. The wastewater flowed through the biogas digesters, produced biogas and the effluent was released back into the ponds far off from the intake point. The amount of wastewater treatment between a combination of measured parameters such as HRT, $\mathrm{pH}$, turbidity, TDS and temperature between the inflow and outflow chambers of the digesters was equally evaluated. HRT's for the system were preset using pre-determined flow rates starting with the lowest achievable HRT and gradually increasing to higher HRTs whilst monitoring the biogas production rates at each retention time.

The produced biogas was combusted openly over 24 hours throughout the course of the experiment using a site constructed pipe burner and it was combusted after being measured with the use of Elster Amco G4 200 diaphragm gas meters (Elster Group, Germany). Influent and effluent wastewater turbidity, temperature and $\mathrm{pH}$ were measured at least three times for each attained HRT during the study and this was done to monitor and record the wastewater parameter change at each time. Biogas production was measured using Elster Amco G4 200 diaphragm gas meters (Elster Group, Germany) and HOBO pulse data loggers (UX90-001, Onset Computer Corporation; Bourne, MA). Readings were taken daily in the morning at 07:00 o'clock and evening at 18:00 o'clock. Ambient temperature was measured with Hobo data loggers UX100-001 set in intervals of 30 minutes. The ambient temperature data loggers were stored in plastic casings to avoid moisture interference. Biogas pressure in the digester was measured using a water column manometer and mechanical spring gauges set up on the biogas network. Pressure readings were taken at the time of gas consumption readings and they were used to calculate (using the half-hemispherical cap Equation (5)) biogas stored in the dome. The total biogas production was calculated by adding the biogas stored in the dome and the amount of biogas combusted through a 24-hour period. 


$$
V_{\text {cap }}=\pi h^{2} *\left(R-\frac{h}{3}\right)
$$

where $h$ is the manometric water height, and $R$ is the dome radius. The gas stored in the system was lessened by the gas stored from the previous day in order not to add up two days' readings as shown by Equation (6).

$$
B_{p}=B_{b}+\left(B_{s t}-B_{s y}\right)
$$

where; $B_{P}$ is the Biogas production, $B_{b}$ is the Gas burned, $B_{s t}$ is Gas stored on the day and $B_{S Y}$ is the gas stored from the previous day. $\mathrm{CO}_{2}$ content in the produced biogas was measured every morning at 07:00 o'clock and evening at 18:00 o'clock during gas meter readings using a $\mathrm{CO}_{2}$ indicator (Brigon Messtechnik $\mathrm{GmbH}$; Rodgau, Germany).

b) Wastewater attributes (COD, Turbidity, $\mathrm{pH}$, Temperature, Conductivity, Total dissolved solids (TDS))

Wastewater treatment and polishing by the system was done by measuring the turbidity of the influent and effluent water with the use of a turbidity tube. Turbidity was calculated with the use of the Neuphelometric turbidity Equation (7) [33].

$$
\text { Depth in centimeters }=244.13 \times \mathrm{NTU}^{-0.662}
$$

Influent and effluent Total Dissolved Solids (TDS), $\mathrm{pH}$, and conductivity were measured the use of the Hanna portable instruments HI-9813-5N (pH/EC/TDS Meter (4.00 mS, $1999 \mathrm{ppm} \mathrm{c/w} \mathrm{HI-1285-5)} \mathrm{whilst} \mathrm{the} \mathrm{temperature} \mathrm{inside} \mathrm{system}$ was measured by the use of HOBO UA-001-64 temperature loggers submerged inside the digesters. The loggers were set to measure the temperature every 30-minutes interval during the study between May and October 2017. Turbidity, COD, TDS and $\mathrm{pH}$ of the wastewater flowing in the anaerobic ponds at the treatment plant was measured in March 2019 in order to obtain a complete set of inflow wastewater characteristics into the ponds.

c) Wastewater pumping volumes and energy requirements

Daily energy consumption records of the wastewater pumps were collected from the utility company records between the periods June 2017 and January to March 2019. The records were used to evaluate the daily energy needs of the pump station through knowing the energy consumption rates as well as the daily wastewater pumped into the ponds.

\section{Results and Analysis}

\section{1) Biogas and Methane production in Libuyu}

The results of the calculated densities (according to Equation (4)) of the methane and carbon dioxide in Livingstone are presented in Table 1 . The volume of methane was obtained by subtracting the percentage of measured $\mathrm{CO}_{2}$ from the biogas and the mass of the produced methane for each digester was obtained by multiplying the volume of methane for each digester by the methane density in Livingstone. 
Table 1. Density of methane and carbon dioxide in Livingstone.

\begin{tabular}{cc}
\hline Parameter & Density $\left(\mathrm{kg} / \mathrm{m}^{3}\right)$ \\
\hline Methane density@sea level $\left(\mathrm{kg} / \mathrm{m}^{3}\right)$ & 0.668 \\
Methane density for Livingstone $\left(\mathrm{kg} / \mathrm{m}^{3}\right)$ & 0.6011 \\
Carbon dioxide density@sea level $\left(\mathrm{kg} / \mathrm{m}^{3}\right)$ & 1.842 \\
Carbon dioxide density for Livingstone $\left(\mathrm{kg} / \mathrm{m}^{3}\right)$ & 1.6576 \\
\hline
\end{tabular}

The results of the obtained volumes of biogas from the Libuyu biogas digesters are shown in Table 2. The sample size of each parameter experimented is bracketed and the results are presented with a mean and standard deviation. The results showed various methane production rates for all different digesters despite some digesters being of the same treatment volume. Results of biogas digester L4-BG 20 in the table were discarded in the analysis due to the system having another wastewater pipe connected and bringing in new sewage to the digester outlet. The results are further presented graphically in Figure 1 in mass methane production in relation to COD inflow and outflow and the HRT. The results in the graph are arranged according to each specific biogas digester and the month of the investigation.

The results show that the COD per cubic meter wastewater entering the biogas systems ranged between 0.74 to $9.24 \mathrm{~kg}$ per day with a mean standard deviation of the results being $3.59 \mathrm{~kg}$ and $2.4 \mathrm{~kg}$ per day respectively. The standard deviation was high due to the huge variance between the smallest and the highest values and a high concentration of results being around the mean value. The methane production however ranged between 0.09 to $3.92 \mathrm{~kg}$ per day with a mean of $1.02 \mathrm{~kg}$ per day and standard deviation of $1.09 \mathrm{~kg}$ per day. Standardizing the results for each digester across the experimental period and analyzing the COD breakdown and methane production rates as shown in Table 3 . The results on the plot of methane production against inflowing COD as in Figure 2 show that the methane production depends much on the inflowing COD concentrations per day for each biogas digester.

The results in the study further show that less COD is removed at high HRT per kilogram of methane produced compared to low HRT's. Plotting the methane production vs COD removal per day, a best fit regression line with Equation (8) and R-squared of 0.8488 was obtained. The R-squared in this equation signified the proportion of variance for a dependent variable $\left(\mathrm{CH}_{4}\right)$ dependent on an independent variable (COD). The results show that the mean concentration of COD entering the biogas systems daily in Libuyu ranged from 0.656 to $4.377 \mathrm{~kg}$ per $\mathrm{m}^{3}$ of wastewater. The standard deviation was $1.416 \mathrm{~kg}$ per cubic meter wastewater. On average, $1.28 \mathrm{~kg}$ of COD was contained in a cubic meter wastewater in the compound. Equating the COD to methane production and the mean COD in wastewater gave Equation (9) which when simplified show that 0.3616 kilograms of methane is produced per cubic meter of the communal wastewater. 


$$
y=0.4187 x-0.4823
$$

The results also show that the range of COD removal per kilogram of methane produced is between $0.51 \mathrm{~kg}$ to $7.94 \mathrm{~kg}$ with a methane production range of 0.2 to 3.92 kilograms' day with a mean of $1.094 \mathrm{~kg}$ per day. Further analysis of the lines show that $3.54 \mathrm{~kg}$ COD is required to be in the biogas system to produce one kilogram of methane.

Table 2. Libuyu biogas digester results (bracketed is the sample size of experimented).

\begin{tabular}{|c|c|c|c|c|c|c|c|c|c|}
\hline $\begin{array}{c}\text { BDG } \\
\text { label/Liquid } \\
\text { Volume }\end{array}$ & $\begin{array}{c}\text { WW Flow } \\
\left(\mathrm{m}^{3} / \text { day }\right) \\
(7)\end{array}$ & $\begin{array}{l}\text { AVG HRT } \\
\text { (day) } \\
(7)\end{array}$ & $\begin{array}{c}\text { AVG WW } \\
\text { Temp (7 days } \\
\text { prior to sample) } \\
\text { (7) }\end{array}$ & $\begin{array}{l}\mathrm{pH} \\
(7)\end{array}$ & $\begin{array}{c}\text { COD (in)- } \\
\text { CALC } \\
\left(\mathrm{mg} / \mathrm{L} \mathrm{O}_{2}\right) \\
(7)\end{array}$ & $\begin{array}{l}\text { COD (out)- } \\
\text { MEAS } \\
\left(\mathrm{mg} / \mathrm{L} \mathrm{O}_{2}\right) \\
(7)\end{array}$ & $\begin{array}{c}\text { Treatment } \\
\text { efficiency (\%) }\end{array}$ & $\begin{array}{l}\text { Biogas } \\
\text { production } \\
\left(\mathrm{m}^{3} / \mathrm{d}\right) \\
(5)\end{array}$ & $\begin{array}{c}\mathrm{CH}_{4}, \mathrm{~g}(\%) \\
\text { (mass } \\
\text { balance) } \\
(5)\end{array}$ \\
\hline L1-BG 40 & $\begin{array}{c}9.925 \pm \\
1.511\end{array}$ & $\begin{array}{c}3.135 \pm \\
0.549\end{array}$ & $\begin{array}{c}23.993 \pm \\
3.252\end{array}$ & $\begin{array}{c}6.953 \pm \\
0.317\end{array}$ & $\begin{array}{c}454.116 \pm \\
113.446\end{array}$ & $\begin{array}{c}273.69 \pm \\
62.736\end{array}$ & $\begin{array}{c}38.8 \% \pm \\
8.3 \%\end{array}$ & $\begin{array}{c}0.805 \pm \\
0.319\end{array}$ & $\begin{array}{c}83.1 \% \pm \\
0.3 \%\end{array}$ \\
\hline L2-BG 30 & $\begin{array}{c}6.561 \pm \\
2.253\end{array}$ & $\begin{array}{c}3.854 \pm \\
1.819\end{array}$ & $\begin{array}{c}23.827 \pm \\
3.075\end{array}$ & $\begin{array}{c}6.896 \pm \\
0.291\end{array}$ & $\begin{array}{c}683 \pm \\
186.923\end{array}$ & $\begin{array}{c}248.19 \pm \\
27.834\end{array}$ & $\begin{array}{c}62.3 \% \pm \\
6.4 \%\end{array}$ & $\begin{array}{c}1.092 \pm \\
0.198\end{array}$ & $\begin{array}{c}83.1 \% \pm \\
0.9 \%\end{array}$ \\
\hline L3-BG 20 & $\begin{array}{c}1.492 \pm \\
0.694\end{array}$ & $\begin{array}{c}14.315 \pm \\
6.71\end{array}$ & $\begin{array}{c}25.08 \pm \\
2.765\end{array}$ & $\begin{array}{l}7.07 \pm \\
0.188\end{array}$ & $\begin{array}{c}765.61 \pm \\
178.611\end{array}$ & $\begin{array}{c}266.619 \pm \\
27.132\end{array}$ & $\begin{array}{c}63.8 \% \pm \\
7.8 \%\end{array}$ & $\begin{array}{c}0.305 \pm \\
0.035\end{array}$ & $\begin{array}{c}82.7 \% \pm \\
0.8 \%\end{array}$ \\
\hline L4-BG 20 & - & - & - & - & - & - & - & - & - \\
\hline L5-BG 20 & $\begin{array}{c}6.705 \pm \\
2.273\end{array}$ & $\begin{array}{c}2.917 \pm \\
1.309\end{array}$ & $\begin{array}{c}24.922 \pm \\
2.55\end{array}$ & $\begin{array}{c}7.101 \pm \\
0.214\end{array}$ & $\begin{array}{c}518.568 \pm \\
219.958\end{array}$ & $\begin{array}{c}330.191 \pm \\
111.863\end{array}$ & $\begin{array}{c}34.6 \% \pm \\
6.12 \%\end{array}$ & $\begin{array}{c}0.347 \pm \\
0.147\end{array}$ & $\begin{array}{c}82.9 \% \pm \\
0.6 \%\end{array}$ \\
\hline L6-BG 20 & $\begin{array}{c}2.467 \pm \\
0.81\end{array}$ & $\begin{array}{c}8.202 \pm \\
3.507\end{array}$ & $\begin{array}{c}24.638 \pm \\
2.774\end{array}$ & $\begin{array}{c}7.03 \pm \\
0.216\end{array}$ & $\begin{array}{c}1004.57 \pm \\
153.02\end{array}$ & $\begin{array}{c}386.91 \pm \\
54.95\end{array}$ & $\begin{array}{c}60.57 \% \pm \\
7.8 \%\end{array}$ & $\begin{array}{c}0.797 \pm \\
0.157\end{array}$ & $\begin{array}{c}81.5 \% \pm \\
0.7 \%\end{array}$ \\
\hline L7-BG10 & $\begin{array}{c}1.607 \pm \\
0.307\end{array}$ & $\begin{array}{c}4.322 \pm \\
1.487\end{array}$ & $\begin{array}{c}25.294 \pm \\
2.254\end{array}$ & $\begin{array}{c}7.017 \pm \\
0.256\end{array}$ & $\begin{array}{c}4765.715 \pm \\
1073.482\end{array}$ & $\begin{array}{c}810.571 \pm \\
76.617\end{array}$ & $\begin{array}{c}82.14 \% \pm \\
4.9 \%\end{array}$ & $\begin{array}{c}4.352 \pm \\
1.314\end{array}$ & $\begin{array}{c}71.7 \% \pm \\
1.2 \%\end{array}$ \\
\hline L8-BG20 & $\begin{array}{c}1.744 \pm \\
0.318\end{array}$ & $\begin{array}{c}9.865 \pm \\
1.765\end{array}$ & $\begin{array}{c}24.175 \pm \\
2.643\end{array}$ & $\begin{array}{c}6.861 \pm \\
0.281\end{array}$ & $\begin{array}{c}1248.123 \pm \\
285.465\end{array}$ & $\begin{array}{c}425.286 \pm \\
46.058\end{array}$ & $\begin{array}{c}65.03 \% \pm \\
5.7 \%\end{array}$ & $\begin{array}{c}0.745 \pm \\
0.144\end{array}$ & $\begin{array}{c}80.3 \% \pm \\
1.4 \%\end{array}$ \\
\hline L9-BG 10 & $\begin{array}{c}0.701 \pm \\
0.146\end{array}$ & $\begin{array}{c}18.165 \pm \\
3.086\end{array}$ & $\begin{array}{c}24.316 \pm \\
2.787\end{array}$ & $\begin{array}{c}7.018 \pm \\
0.229\end{array}$ & $\begin{array}{c}1159.215 \pm \\
182.202\end{array}$ & $\begin{array}{c}365.643 \pm \\
30.778\end{array}$ & $\begin{array}{c}68.03 \% \pm \\
3.7 \%\end{array}$ & $\begin{array}{c}0.217 \pm \\
0.1\end{array}$ & $\begin{array}{c}80.8 \% \pm \\
0.9 \%\end{array}$ \\
\hline
\end{tabular}

Table 3. Libuyu biogas digester COD, methane and HRT relation (L-Libuyu).

\begin{tabular}{|c|c|c|c|c|c|c|c|c|c|}
\hline Biogas System & $\begin{array}{c}\text { Total COD in } \\
(\mathrm{kg})\end{array}$ & $\begin{array}{l}\text { Total COD } \\
\text { rem }(\mathrm{Kg})\end{array}$ & $\begin{array}{c}\text { System } \\
\text { Temp }\left({ }^{\circ} \mathrm{C}\right)\end{array}$ & $\mathrm{CH} 4 \mathrm{~kg} /$ day & HRT (Days) & $\begin{array}{c}\text { COD in/HRT } \\
(\mathrm{Kg} / \text { day })\end{array}$ & $\begin{array}{c}\text { CODrem /HRT } \\
\text { (Kg/day) }\end{array}$ & $\begin{array}{l}\text { CODrem } \\
/ \mathrm{CH} 4(\mathrm{Kg})\end{array}$ & $\begin{array}{l}\text { Removal } \\
\text { Efficiency }\end{array}$ \\
\hline L1-BG 40 & 4.507 & 1.791 & 23.993 & 0.458 & 3.135 & 1.438 & 0.571 & 3.910 & $40 \%$ \\
\hline L2-BG 30 & 4.481 & 2.853 & 23.827 & 0.621 & 3.854 & 1.163 & 0.740 & 4.594 & $64 \%$ \\
\hline L3-BG 20 & 1.142 & 0.744 & 25.080 & 0.173 & 14.315 & 0.080 & 0.052 & 4.303 & $65 \%$ \\
\hline L5-BG 20 & 3.477 & 1.263 & 24.922 & 0.197 & 2.917 & 1.192 & 0.433 & 6.412 & $36 \%$ \\
\hline L6-BG 20 & 2.478 & 1.524 & 24.638 & 0.453 & 8.202 & 0.302 & 0.186 & 3.364 & $61 \%$ \\
\hline L7-BG10 & 7.659 & 6.356 & 25.294 & 2.205 & 4.322 & 1.772 & 1.471 & 2.883 & $83 \%$ \\
\hline L8-BG20 & 2.177 & 1.435 & 24.175 & 0.423 & 9.865 & 0.221 & 0.145 & 3.393 & $66 \%$ \\
\hline L9-BG 10 & 0.813 & 0.556 & 24.316 & 0.124 & 18.165 & 0.045 & 0.031 & 4.486 & $68 \%$ \\
\hline Mean & $\underline{3.342}$ & $\underline{2.065}$ & $\underline{24.531}$ & $\underline{0.582}$ & $\underline{8.097}$ & $\underline{0.776}$ & $\underline{0.454}$ & $\underline{4.168}$ & $\underline{60 \%}$ \\
\hline$\underline{\mathrm{SD}}$ & $\underline{2.225}$ & $\underline{1.869}$ & $\underline{0.535}$ & $\underline{0.678}$ & $\underline{5.693}$ & $\underline{0.687}$ & $\underline{0.484}$ & $\underline{1.089}$ & $=$ \\
\hline
\end{tabular}




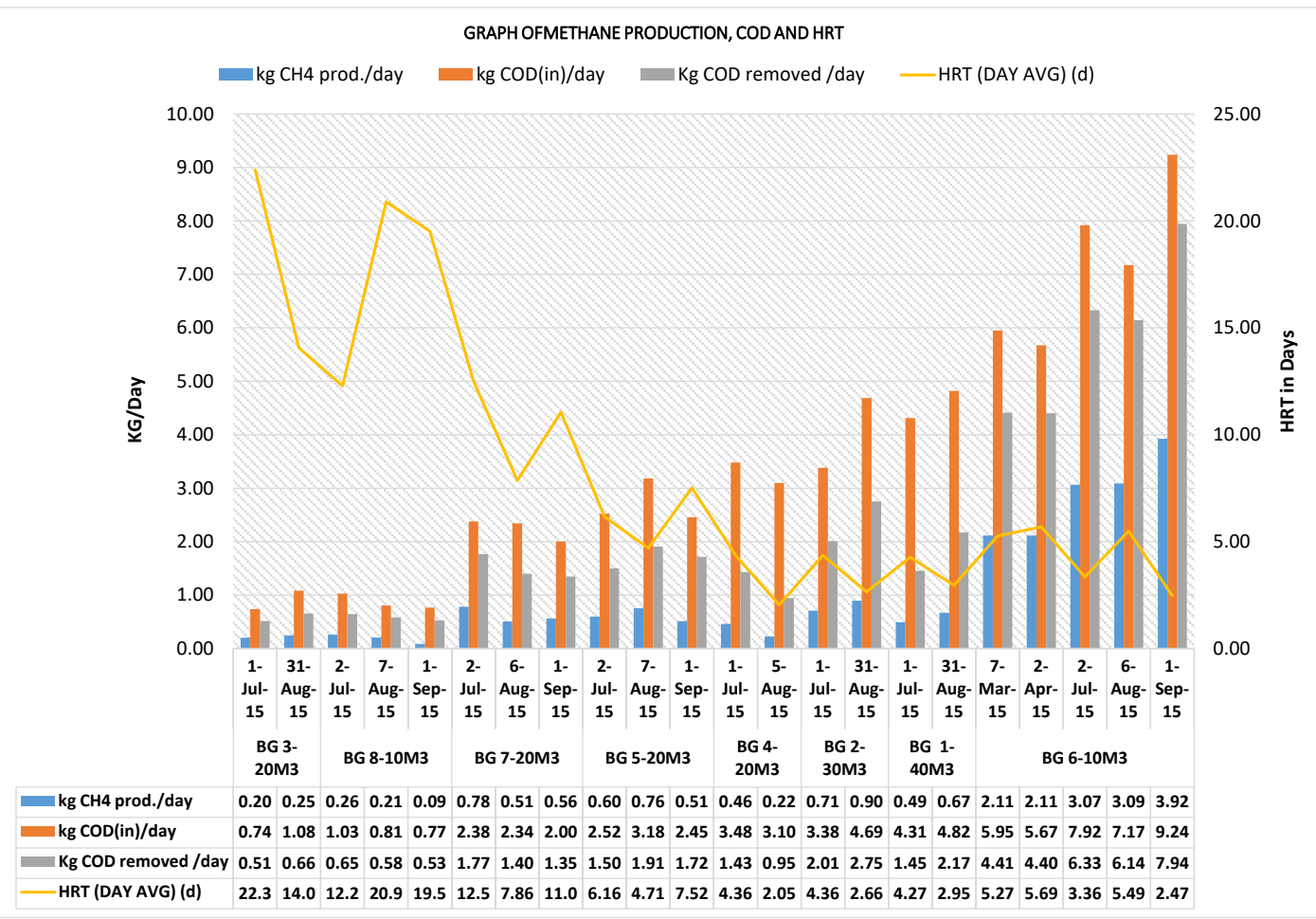

Figure 1. Biogas production per COD concentration rate entering biogas units in Libuyu.

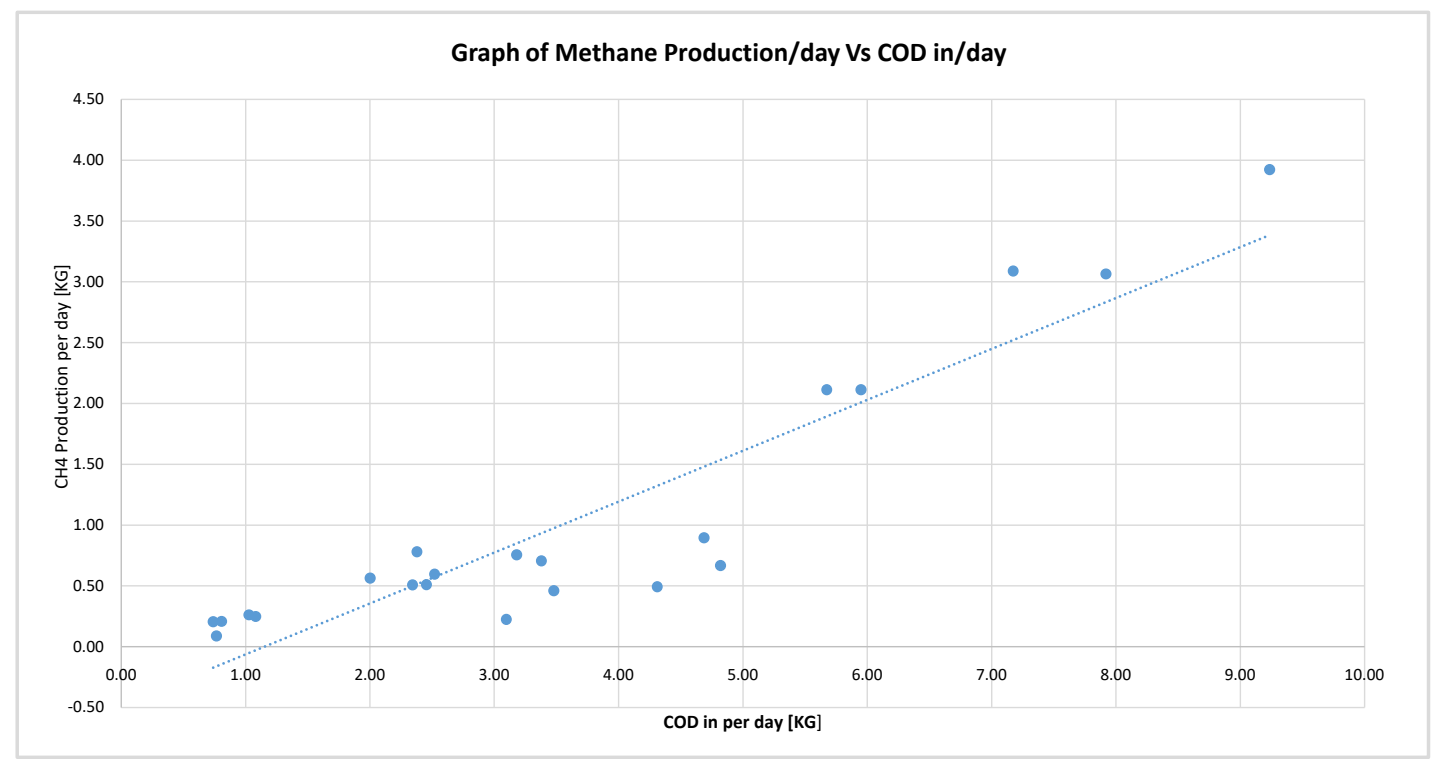

Figure 2. Methane production per COD inflow.

Equating the COD for a kilogram of methane produced and the mass of COD in a cubic meter of wastewater as in Equation (9) and simplifying, the results gave out that 1.15 kilograms of COD per $\mathrm{m}^{3}$ wastewater is required per cubic meter of wastewater for a measurable methane production.

$$
3.54 \mathrm{~kg} \mathrm{COD} / \mathrm{kg} \mathrm{CH}_{4}=1.28 \mathrm{~kg} \mathrm{COD} / \mathrm{m}^{3} \text { waste water }
$$

Plotting a linear graph with a zero intercept in Figure 3 and simplifying and 
solving the equation gave out that $2.15 \mathrm{~kg}$ of $\mathrm{COD}$ is broken down per kilogram of methane produced. Combining the methane production rate with the amount of COD contained per cubic meter wastewater as in Equation (10) showed that $0.6 \mathrm{~kg}$ of methane is produced per cubic meter of communal wastewater.

$$
2.15 \mathrm{~kg} \mathrm{COD} / \mathrm{kg} \mathrm{CH}_{4}=1.28 \mathrm{~kg} \mathrm{COD} / \mathrm{m}^{3} \text { waste water }
$$

Simplified results show that $1.67 \mathrm{~m}^{3}$ of wastewater with a COD concentration of $2120 \mathrm{mg} / \mathrm{l}$ is needed to produce a kilogram of methane in Libuyu compound and the numerical analysis of the COD removal efficiency from the wastewater was at 72 percent. A regression line of COD removal per COD inflow in Figure 4 indicate that the amount of COD removed depends on the influent COD concentration per unit time and not the HRT of the wastewater in the system. However, more COD is removed per $\mathrm{kg}$ of methane produced daily at high HRT.

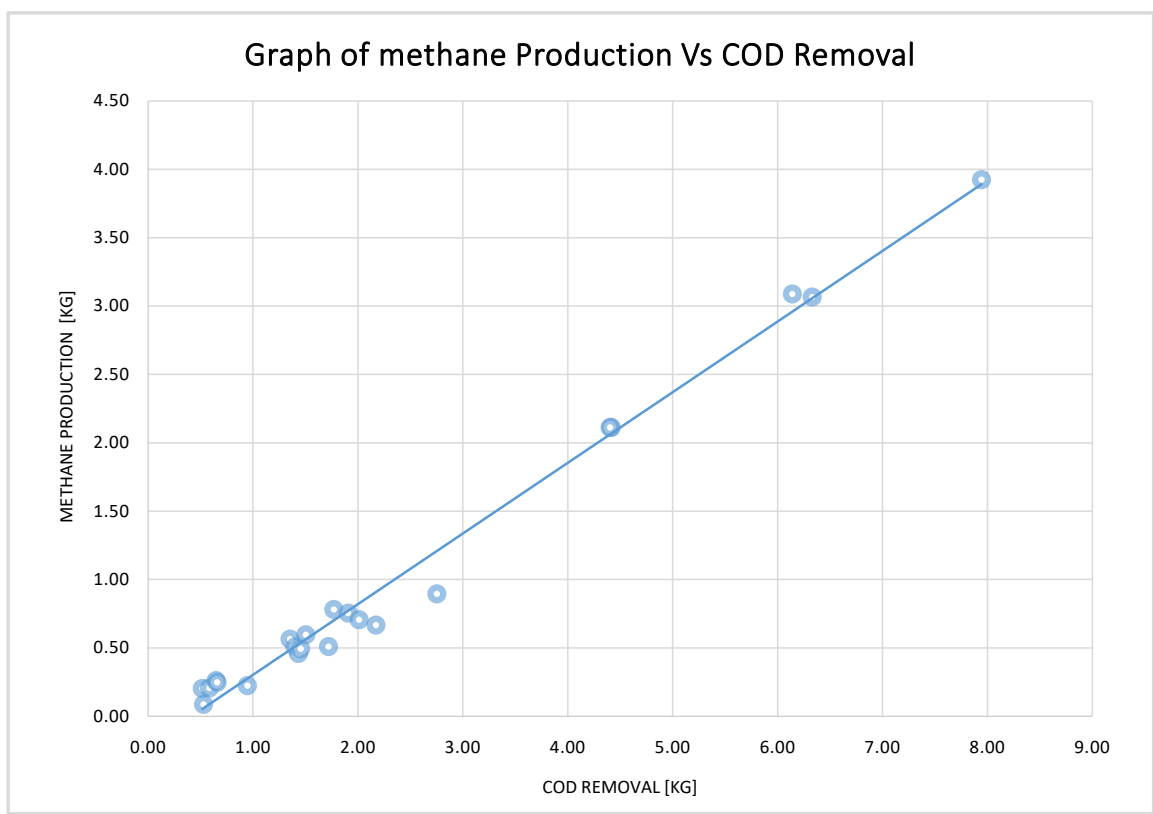

Figure 3. Graph of Methane production versus COD removal from the wastewater

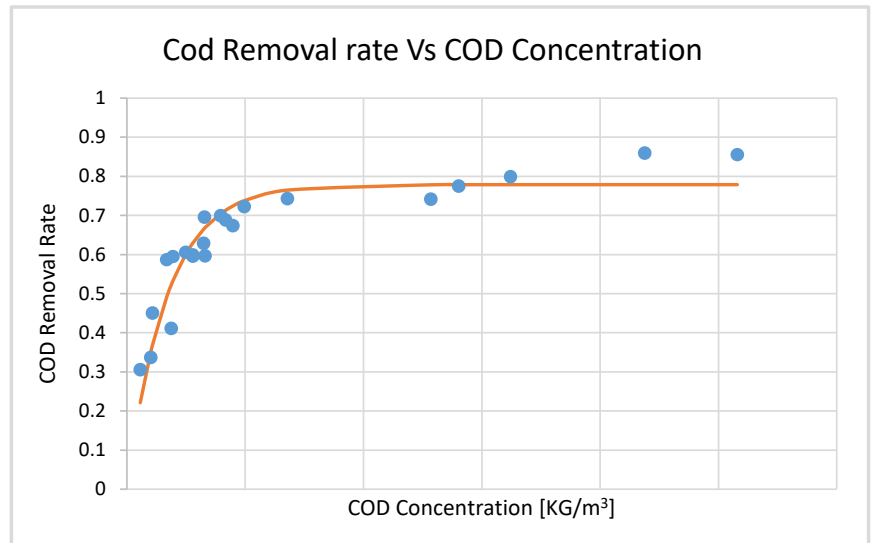

Figure 4. Graph of COD removal vs COD concentration in the system. 
Figure 5 show the relation between retention time, COD removal and methane. The graphs show that even under low hydraulic retention time, the rate of COD removal is high when the inflow COD concentration is high and the biogas production rates depend on the amount of COD removed. With a HRT range of between 2 to 23 days and COD loads range of $0.74 \mathrm{~kg}$ to $9.24 \mathrm{~kg}$ per $\mathrm{m}^{3}$, the COD removal efficiency ranged between 27.5 to 86 percent. The results further show that the higher the COD concentration entering the system, the higher the methane production potential of the system. Incremental COD concentration loads per digester unit also gave incremental biogas production irrespective of the retention time.

The results of the study on methane production, consumed and lost into the environment conducted in 2019 from the seven biogas digesters are shown in Table 4. For uniformity of analysis, the methane content of the measured biogas was calculated as in the first study of the digesters.

Taking results from the $40 \mathrm{~m}^{3}$ digester with 39 households' connections with a household size of 5.8. A maximum methane production of $4.18 \mathrm{~kg}$ per day was found with a per capita per day methane production at 18.5 grams on the assumption that all connected households use the new toilet facilities at the households.

\section{2) Biogas production at Dambwa}

The wastewater inflow and outflow into the stabilization ponds photometrical tested in the University of Zambia laboratory in February 2019 is shown in Table 5 .

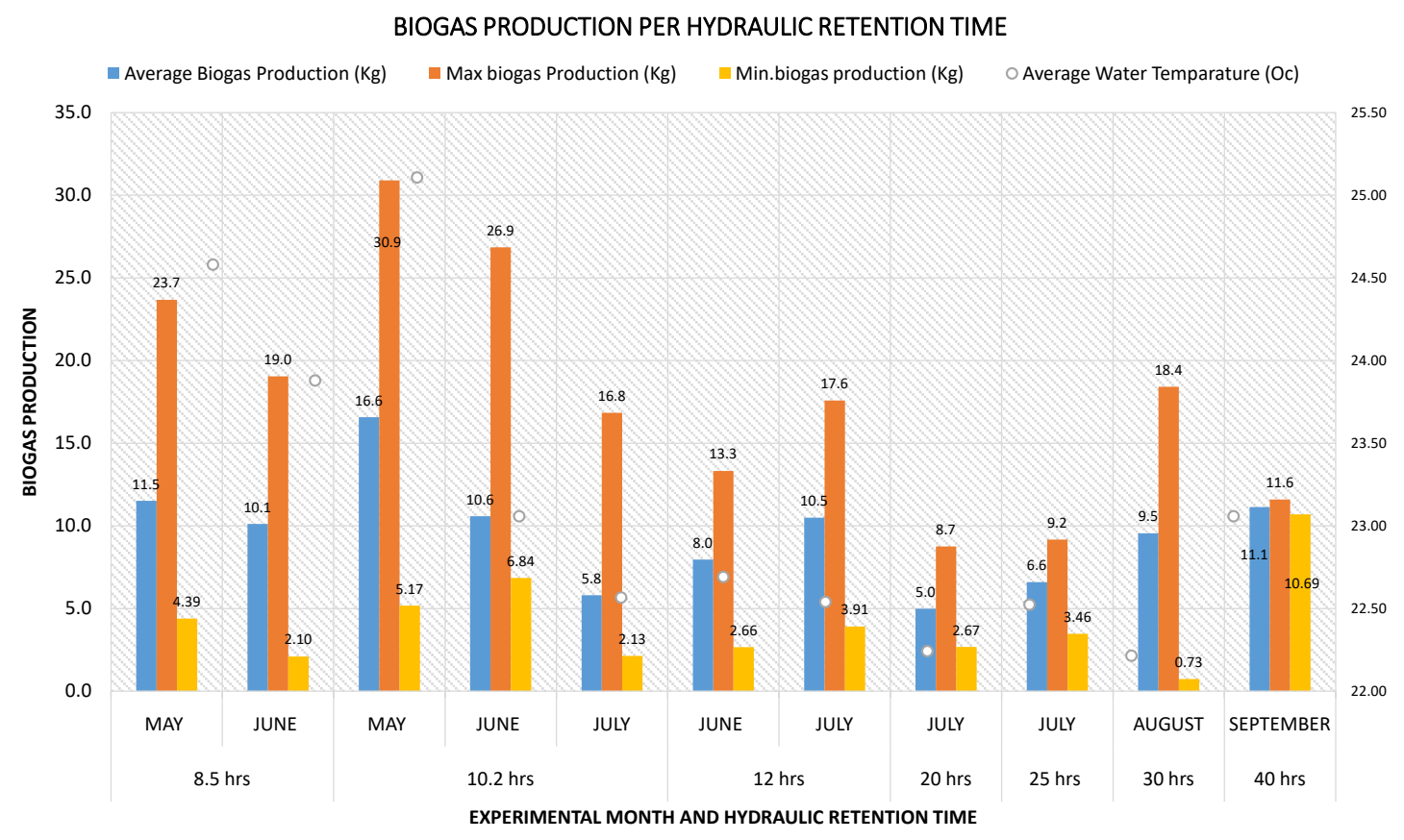

Figure 5. Results of the biogas production rates against retention time and the temperature variation between the months of the study. 
Table 4. Methane production and consumption from biogas units in Libuyu.

\begin{tabular}{|c|c|c|c|c|c|c|c|}
\hline $\begin{array}{c}\text { Biogas } \\
\text { Digester \# }\end{array}$ & $\begin{array}{c}\text { Number of } \\
\text { Sewer Households } \\
\text { Connected \# }\end{array}$ & $\begin{array}{l}\text { Biogas } \\
\text { Production } \\
\left(\mathrm{m}^{3} / \text { day }\right)\end{array}$ & $\begin{array}{c}\text { Maximum } \\
\text { biogas usage } \\
\left(\mathrm{m}^{3} / \text { day }\right)\end{array}$ & $\begin{array}{l}\text { Carbon Dioxide } \\
\text { Percentage in } \\
\text { the Gas (\%) }\end{array}$ & $\begin{array}{c}\text { Maximum } \\
\text { Methane } \\
\text { production (kg/day) }\end{array}$ & $\begin{array}{c}\text { Maximum } \\
\text { Methane usage } \\
\text { (kg/day) }\end{array}$ & $\begin{array}{c}\text { Excess } \\
\text { Methane per day } \\
\text { (kg/day) }\end{array}$ \\
\hline L1-BG 40 & 39 & 8.7 & 1.1 & $20 \%$ & 4.18 & 0.53 & 3.65 \\
\hline L2-BG 30 & 39 & 4.23 & 1.6 & $18 \%$ & 2.08 & 0.99 & 1.09 \\
\hline L3-BG 20 & 17 & 2.78 & 0.83 & $13 \%$ & 1.45 & 0.45 & 1.00 \\
\hline L5-BG 20 & 27 & 3.05 & 2.3 & $28 \%$ & 1.32 & 1.16 & 0.16 \\
\hline L6-BG 20 & 27 & 0.72 & 0.7 & $18 \%$ & 0.35 & 0.35 & 0.00 \\
\hline L7-BG10 & 16 & 6.23 & 1.28 & $30 \%$ & 2.60 & 0.91 & 1.69 \\
\hline L9-BG 10 & 11 & 0.9 & 0.9 & $20 \%$ & 0.44 & 0.40 & 0.04 \\
\hline Total & 176 & 26.61 & 8.71 & 1.47 & 12.42 & 4.78 & 7.60 \\
\hline
\end{tabular}

Table 5. Parameters of wastewater inflow and outflow of the Dambwa stabilization ponds.

\begin{tabular}{ccc}
\hline SAMPLE POINT DESCRIPTION & RAW sewage (Inlet) & SWSC Effluent (Tertiary Ponds) \\
\hline pH & 7.3 & 8.2 \\
Turbidity (cm) & 3.9 & 2.85 \\
Turbidity (NTU) & 517.41 & 831.00 \\
TDS (mg/L) & 480.3 & 424.05 \\
Nitrate (mg/L) & 22.59 & 49.91 \\
Nitrite (mg/L) & 0.04 & 0.12 \\
Ammonia (mg/L) & 0.05 & 0.06 \\
Dissolved Oxygen, mg/L & 0.4 & 3.7 \\
COD, mg/L & 416 & 280 \\
BOD, $\mathrm{mg} / \mathrm{L}$ & 260 & 170
\end{tabular}

Biogas production from the Dambwa biogas digesters was analyzed on the first biogas digester receiving the untreated sewage. Results of retention times and the biogas production rates at the study site is shown in Table 6 and the graphical representation of the results showing the relationship between HRT, temperature and biogas production is shown in Figure 5. The results show that the biogas digester produced high amounts of biogas at a retention time of 10.2 hours against the lower retention time of 8.5 hours and other high retention times of $12,20,25,30$ and 40 hours. The produced biogas was normalized into kilograms by the use of Equation (4) with relations between height, atmospheric pressure, density and temperature of the area around study site. The methane $\left(\mathrm{CH}_{4}(\mathrm{~g})\right)$ content was computed by subtracting the calculated mass of the measured $\mathrm{CO}_{2}$ from the computed biogas mass.

During a 10-hour retention time, a minimum and maximum biogas mass of $5.17 \mathrm{~kg}$ and $30.9 \mathrm{~kg}$ per day were produced respectively with an average of 16.6 $\mathrm{kg}$ per day. The shortest retention time attained during the experiment was 8.5 hours and it was attained in May and June 2017. At this retention time a minimum and maximum biogas mass of $4.39 \mathrm{~kg}$ per day and $23.7 \mathrm{~kg}$ per day was produced with an average of $11.5 \mathrm{~kg}$ per day. 
Figure 6 presents the normalized methane production per COD removed from the wastewater and they show that more COD is removed per kilogram methane produced under lower temperature conditions $\left(22.21^{\circ} \mathrm{C}-22.57^{\circ} \mathrm{C}\right)$. Thus the methane production increases under higher temperature conditions $\left(23.06^{\circ} \mathrm{C}-25.11^{\circ} \mathrm{C}\right)$ while COD removal rates per kilogram methane produced increases under lower temperature conditions.

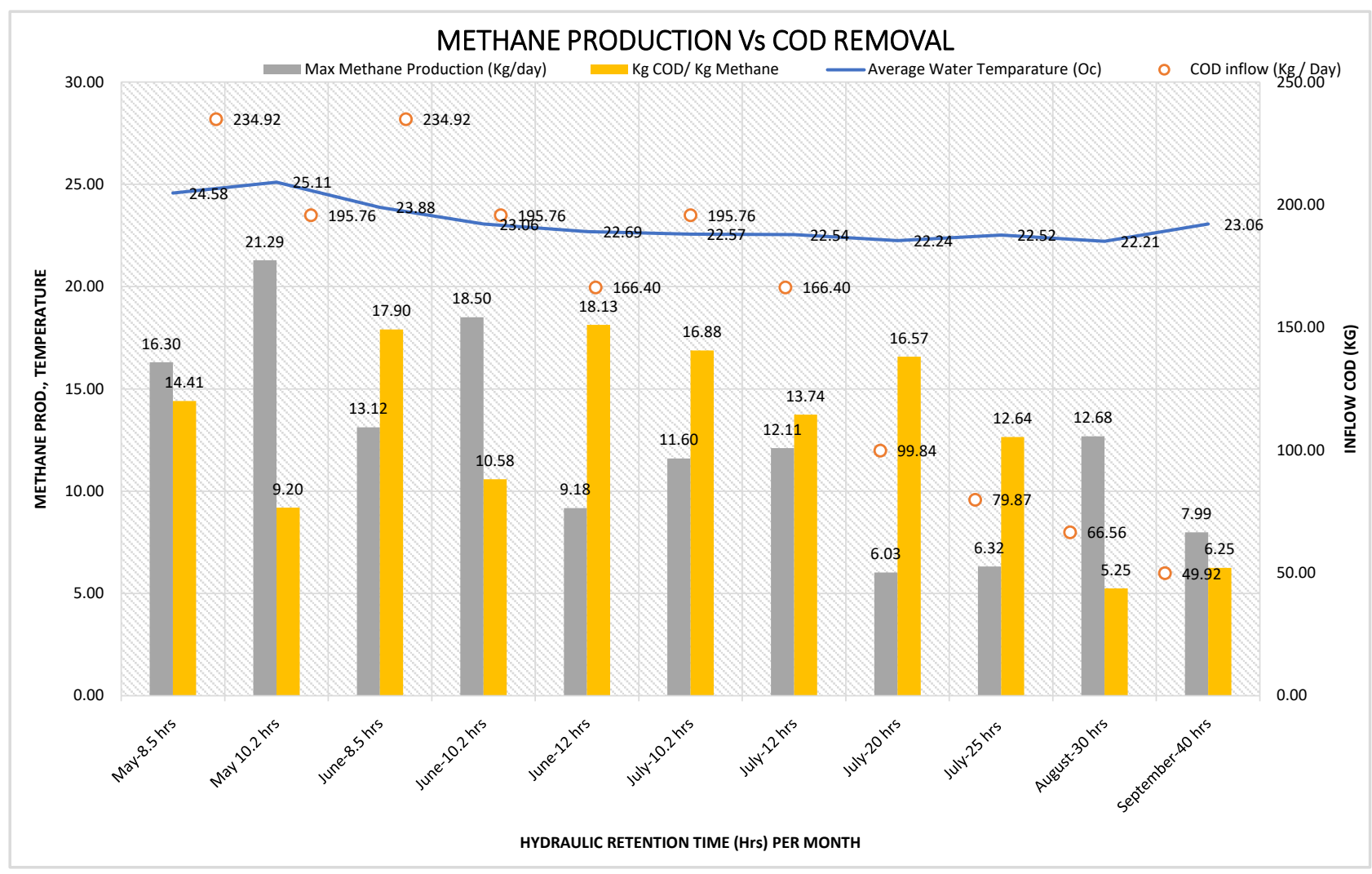

Figure 6. Methane production (kg) per COD removal rate (kg over time).

Table 6. Measured parameters of Dambwa site (temperature, HRT, biogas production, $\mathrm{CO}_{2}$ content, methane content).

\begin{tabular}{cccccccccc}
\hline Month & $\begin{array}{c}\text { Average Water } \\
\text { Temperature }\end{array}$ & $\begin{array}{c}\text { HRT } \\
(\mathrm{hrs})\end{array}$ & $\begin{array}{c}\text { Max biogas } \\
\text { Production } \\
\left(\mathrm{m}^{3}\right)\end{array}$ & $\begin{array}{c}\text { Min. biogas } \\
\text { production } \\
\left(\mathrm{m}^{3}\right)\end{array}$ & $\begin{array}{c}\text { Average } \\
\text { Biogas } \\
\text { Production }\left(\mathrm{m}^{3}\right)\end{array}$ & $\begin{array}{c}\text { Average } \mathrm{CO}_{2} \text { Max. methane Min. Methane } \\
\text { Content }(\%)\end{array}$ & $\begin{array}{c}\text { Average } \\
\text { content }(\mathrm{kg})\end{array}$ & $\begin{array}{c}\text { Methane } \\
\text { content }(\mathrm{kg})\end{array}$ \\
Content $(\mathrm{kg})$
\end{tabular}




\section{c) Elaboration of energy production potential of biogas digester con- nected to municipal sewer line}

With a retention time of 10.2 hours in the Dambwa digesters, the study show that a biogas digester is able to effectively treat about 2.4 times the designed constructed volume. Therefore, with the fixed dome digester volume at the site being 203 cubic meters, the volume of wastewater passing through the digester system per day was approximately 480 cubic meters. The wastewater at this retention time yielded maximum biogas of 64.375 grams and minimum yield of 34.58 grams per cubic meter of wastewater that passed through the system for treatment. Assuming a constant COD inflow into the system throughout the dry season due to a constant household connection during the study period and the once off COD measurement in March 2019 being 0.416 grams per liter, the total COD entering the biogas treatment unit per day was approximately 196,500 grams. However, applying Soto's factors for the Dambwa site conditions and the methane production from the facility, the maximum and minimum daily COD removal rates of the facility were 102,290 grams and 60.00 grams for the hot (August and September) and cold (May to July) months respectively. This represents COD removal rates of $52 \%$ and $30.5 \%$ for the aforementioned months respectively. The TDS concentration measurements for digester inlets and outlets showed a reduction in dissolved solids in the outlets from the inlets for eight out of twelve measurements on the 10, 20, 30 and 40 hours' retention times. The maximum TDS reduction of $26 \%$ occurred on the 30 hours' retention time and the minimum reduction of $8 \%$ occurred at the 40 hours' retention time. The 10 hours' retention time had an average TDS reduction of $14 \%$ which almost conceded with the average experimental TDS reduction of $16 \%$. However, there was a turbidity reduction across all retention times with an average reduction of $54.6 \%$. The highest wastewater turbidity inflow was 538 NTU which was reduced to 132 NTU bringing the turbidity reduction of $75 \%$ by the unit.

Temperature in the Dambwa experimental results also proved to be very critical in affecting the biogas production rates. Temperature versus biogas analysis at retention times of 8.5 hours and 10 hours between May, June and July showed an influence on the biogas production rate as biogas decrease rates of 2 to 2.9 kilogram were recorded per degree change in temperature respectively. The results confirmed that temperature has an effect on biogas production and increases the biogas production between 4 to 8 grams per cubic meter per degree increase in temperature. The effect of temperature in literature is explained by its effect of the production of free ammonia in wastewater of which the free ammonia is researched to be a powerful inhibitory effect on anaerobic processes (Burak \& Orhan, 2013). The Østergard Equation (11) shows the effect of temperature on free ammonia production (Hansen, et al., 2004).

$$
\frac{\mathrm{NH} 3}{\mathrm{TNH} 3}=1 /\left(1+\frac{10^{-\mathrm{PH}}}{10^{-\left(0.09018+\left(\frac{2729.92}{T(k)}\right)\right)}}\right)
$$


Analysis of Østergard's equation for free ammonia concentration with relation to temperature and $\mathrm{pH}$ show that high temperature and low $\mathrm{PH}$ reduces free ammonia production in an anaerobic system and low temperature and high $\mathrm{PH}$ increases the free ammonia to total ammonia ratio in a given system thereby the free ammonia inhibiting anaerobic processes.

\section{4) Evaluation of levelized costs of energy production through treatment facilities}

From the energy consumption, it was found that the pump station at the Eureka pump station consumes an average $546 \mathrm{Kwh}$ electrical energy per day operating on a $55 / 75 \mathrm{KW} / \mathrm{Hp}$ pump running $81 \%$ of the day. The pump has a $19 \%$ stoppage in between running intervals. This is because the pump is run on/off with a water level sensible switch submerged in the receiving wastewater sump. The details of the pump are 380 Volts, 104 Ampere and $50 \mathrm{~Hz}$ frequency. The pump is rated with an efficiency rate of $93.5 \%$ and rotates at 1475 revs per minute. Table 6 summarize the wastewater pumping rates and energy consumption at the Eureka pump station.

Simulation to a pump station with a biogas engine which could generate as much energy required to pump about $9009 \mathrm{~m}^{3}$ of wastewater per day, the Cummins $6 \mathrm{BT}$ biogas engine of $45 \mathrm{kw}$ power production capacity was selected. The engine would be able to meet the energy requirements at a low specific fuel consumption rate of $0.5 \mathrm{~m}^{3} / \mathrm{kwh}$ as specified by the engine [34]. The required amount of biogas was evaluated using the specific energy needs of the pump station and the specific fuel consumption rate of the Cummins engine 6BT engine. At normal temperature of $22^{\circ} \mathrm{C}$, pressure of 1115 mbar and an average 920-meter height above sea levels, the biogas density with measured $\mathrm{CO}_{2}$ content of $10 \%$ was calculated at $0.7854 \mathrm{~kg} / \mathrm{m}^{3}$.

The required biogas volume needed at the plant is equal to;

$546 \mathrm{kWh}$ by $0.5 \mathrm{~m}^{3}$ per $\mathrm{kWh}$ and equals $273 \mathrm{~m}^{3}$ of biogas

The mass of biogas needed is therefore; 273 by 0.785 equal to 214,140 grams

Based on the calculations presented in the previous section it can be said that with 34.58 grams of biogas produced per cubic meter of wastewater at the ponds, the maximum volume of wastewater needed to produce adequate gas for energy production is given by

$$
\begin{aligned}
\text { Required Wastewater } & =\frac{\text { biogas mass required }}{\text { biogas production per cubic wastewater }} \\
& =\frac{214140 \text { grams }}{34.58 \text { grams } / \mathrm{m}^{3}}
\end{aligned}
$$

which equals to $6192.6 \mathrm{~m}^{3}$ of waste water per day

With the wastewater being retained inside the digester for treatment and biogas production for only $10 \mathrm{hrs}$ of the day (is $42 \%$ of the day), the required anaerobic volume for gas generation was equal to;

42 percent by 6192.6 which equals to $2580 \mathrm{~m}^{3}$ of digester volume.

Considering constructing $203 \mathrm{~m}^{3}$ digesters, the number of units required is 13 . 
The construction cost for each unit was approximated at USD 13,000 bringing the anaerobic investment cost to USD169,000.

\section{5) Levelized Cost of Energy Production Using Wastewater in Dambwa}

The cost of the $45 \mathrm{kWh}$ Cummins biogas engine costs approximately USD 10,000 and the potential amount of energy to be produced per year by the system is about 199,290 kWh. With an estimated biogas digester dome lifespan of 20 years, the depreciation cost of the digester units is calculated using Equation (12) which gives digester depreciation cost to equal to:

$$
\text { Depreciation }=\frac{\text { Cost }}{\text { Lifespan }} ; \frac{\text { USD } 169000}{20 \text { years }}=\text { USD 8450/year }
$$

The engine has a running rate of 8000 hours per year with an engine overhaul time of 60,000 hours and the site condition requires an average availability of $80 \%$ due to the start/off times. Therefore, the engine operation hours would be 6400 hours per year bringing an engine overhaul life to 9.375 years. The cost of the biogas engine being USD 10,000, the depreciation cost is also calculated using Equation (13) and gives the depreciation cost of USD 1067. The operations and maintenance $(\mathrm{O} \& \mathrm{M})$ cost of the facilities was calculated from the salary payments of a sewer operator whose gross salary at the time of investigation was USD 300 per month. The pump station operates on two operators thereby bringing the annual O\&M cost to USD 7200. The levelized cost of energy for the plant was then calculated using Equation (13).

$$
\mathrm{LCOE}=\frac{(\text { Plant depreciation }+ \text { Engine depreciation })+\mathrm{O} \& \mathrm{M} \text { costs }}{\text { Potential energy generation per year }}
$$

The levelized cost of energy equaled

$$
\begin{aligned}
& =\frac{\text { USD } 8450+\text { USD } 1066.7+\text { USD } 8000}{199290 \mathrm{kWh}}=\frac{\text { USD } 17516.7}{199290 \mathrm{kWh}} \\
& \text { USD } 0.08789 / \mathrm{kWh}=\text { US cents } 9 / \mathrm{kWh}
\end{aligned}
$$

The calculated LCOE is very competitive to the board recommended market price of 17 US cents/kwh electric energy [35].

\section{Discussion}

1) Benefits of using units of anaerobic treatment systems and how those can be applied in future sanitation solutions

With the use of anaerobic digestion for wastewater treatment, the energy needs of treatment plants could be met with anaerobic treatment processes and use of machinery to convert the generated gas into heat and power. Colon et al., have found that 0.44 normal liters of methane can be produced per gram of COD broken down [7]. These values are comparable to obtained values of 0.592 liters per gram of COD in Libuyu communal wastewater. The values closely correspond to Park et al., findings of $0.21 \mathrm{~m}^{3}$ methane per kilogram COD [36]. In terms of volumetric load for biogas production, the digesters in Dambwa gave an optimum methane production of 64.3 grams (equivalent to 82 liters at site 
methane density of $0.6011 \mathrm{~kg} / \mathrm{m}^{3}$ ) per cubic meter of wastewater flow through the system. This study shows that the rate of biogas production depends much on the COD concentration and temperature of the wastewater and little on the HRT. The COD removal rates of biogas digesters in the compound showed potential of up to $71 \%$ COD removal. With the removal rate depending on the COD concentration, high COD concentrated wastewater produced more biogas and had higher COD removal rates. Further, more COD is removed per unit methane production at lower temperatures.

Municipal wastewater at the Dambwa site digesters however produces ten times less biogas per cubic meter of wastewater treated compared to the domestic wastewater treated in biogas digesters in Libuyu. The low biogas production per cubic meter of wastewater at the ponds show that the municipal wastewater in the ponds is less concentrated compared to the Libuyu communal wastewater. This was confirmed by the pond inflow COD concentration being $416 \mathrm{mg} / \mathrm{L}$ and the inflow in Libuyu having an average of $1280 \mathrm{mg} / \mathrm{l}$. However, the amount of electrical energy that can be produced could exceed the calculated amounts as the biogas quality is higher than the quality specified by the engine manufacturer. The engine manufacturer requires a biogas quality of $+50 \%$ methane content. The measured $\mathrm{CO}_{2}$ content of the produced biogas was $10 \%$, hence it can be assumed that the biogas methane content is above $80 \%$ and the other $10 \%$ being $\mathrm{N}_{2}$ [29]. This is based on the assumption that the BOD inflow is around $200 \mathrm{mg} / \mathrm{l}$ since the measured COD was at $416 \mathrm{mg} / \mathrm{l}$.

Data on the biogas production from the municipal wastewater in the Dambwa site biogas unit show that a cubic meter of wastewater requires about 0.42 cubic meter of digester volume per day on a mean HRT of Hours to produce 23.8 grams of methane. Based on a brick construction cost of USD13,000 for a 203 cubic meter digester, this translates to a cubic meter construction cost of USD270 which can treat $2.4 \mathrm{~m}^{3}$ wastewater daily over a minimum operation period of 20 years. The facility depreciation cost was estimated at USD13.5 per year per cubic meter of wastewater treated. The total cost of investment for the power generation equipment was calculated at USD 68,000 per kW with a COD removal rate of 21,900 kilograms per annum. In COD removal investment, USD 13 cents is required to be invested in the facility per $\mathrm{kg}$ COD to be removed. With investment in wastewater treatment and energy recovery, the Dambwa municipal wastewater treatment facility could cover be covering about $12.5 \%$ of operations and maintenance costs in its first year of operations from energy savings. The levelised cost of energy production from the Dambwa treatment units of USD 9 cents per kWh is competitive to the energy production costs in Zambia. The study show that methane can be produced anaerobically and most efficiently from continuously flowing human sewage at hydraulic retention times between 8.5 and 10.2 hours. The findings further confirm that temperature has significant effect on methane production and increases the methane production between $4 \mathrm{~g}$ to $8 \mathrm{~g}$ per ${ }^{\circ} \mathrm{C}$ change in temperature. This was approximately 1.2 percent biogas production change per degree change in the system temperature. 
2) Feasibility of partially or complete support of energy requirement of treatment plants with biogas produced from sewage digestion

The Dambwa municipal wastewater treatment facility show an electric energy production potential of $0.1 \mathrm{kwh}$ per cubic meter of wastewater treated. With an approximated wastewater production of $9014 \mathrm{~m}^{3}$ per day, the plant is capable of having a $40 \mathrm{~kW}$ capacity plant. This amount of energy would be adequately in excess to be consumed by the pump station alone as it consumes a maximum $546 \mathrm{kWh}$ per day. Therefore, the excess $414 \mathrm{kWh}$ could be sold to the utility ZESCO at an energy regulation board recommended market price of market USD 17 cents per kWh electric energy [35]. This is profitable to the utility as it is twice the production costs. For wastewater treatment purposes, anaerobic treatment could benefit the environment by saving 800 grams of oxygen per cubic meter of wastewater treated.

\section{Conclusion}

Sewage is a valuable resource that could provide renewable energy at very economical rates when treated anaerobically. In the process of anaerobic treatment of wastewater for the production of renewable energy, extra benefits are realized as huge loads of organic pollutants in form of COD are removed from the wastewater. The analysis in this paper show that as much as 2.15 kilograms of COD in highly polluted wastewater was converted into a kilogram of methane fuel. The results also show that more methane is produced per unit wastewater with increasing temperature of the wastewater under treatment. The results of this study encourage and promote the use of anaerobic treatment with biogas capture for human wastewater treatment. This approach of using digesters for primary treatment of wastewater make use of human wastewater for energy production for both domestic and industrial use and at the same time save the environment greenhouse gases produced during primary wastewater treatment in sewage stabilization ponds. The implementation of biogas units for primary wastewater treatment and energy recovery also entails less land requirements for wastewater treatment. Therefore, communities lacking Sewered sanitation facilities and have inadequate land for the implementation of centralized wastewater treatment facilities could use decentralized wastewater treatment plants and utilize the anaerobic treatment with energy recovery approaches and utilize the energy on the benefit of the plant operations and the proximal community.

\section{Acknowledgements}

Thanks to go the Bremen Overseas Research and Development Association (BORDA) Africa region and BORDA Africa director Jutta Camargo for giving financial and material support for this work. Special thanks go to Jeannette Laramee for sharing data collected from Libuyu and allowing the use in this study. Special thanks also go to Southern Water and Sewerage Company Limited (SWASCo) for allowing the study to use their biogas facilities in the vicinity of 
the ponds, allowing the connection of sewage to run into the biogas facilities and the corporation of the company personnel in giving access to study facilities and required information.

\section{Conflicts of Interest}

The authors declare no conflicts of interest regarding the publication of this paper.

\section{References}

[1] Scarlet, N., Scarlet, N. and Scarlet, N. (2015) Evaluation of Energy Potential of Municipal Solid Waste from African Urban Areas. Renewable and Sustainable Energy Reviews, 50, 1269-1286. https://doi.org/10.1016/j.rser.2015.05.067

[2] Touati, K., et al. (2017) Pressure Retarded Osmosis. Academic Press, London. https://doi.org/10.1016/B978-0-12-812103-0.00002-7

[3] UN-Habitat (2015) National Report on the Third United Nations Conference on Housing and Sustainable Urban Development. Zambia Final Report.

[4] Tembo, Y. (2014) Rapid Urbanisation in Zambia. The Challenges Facing Our Cities and Towns. Grin Verlag, Munich.

[5] Mulenga, C.L. (2003) The Case of Lusaka, Zambia. University College London, London.

[6] NWASCO (2018) Urban and Peri-Urban Water Supply and Sanitation Sector Report 2017. National Water Supply and Sanitation Council, Lusaka.

[7] Colón, J., et al. (2015) Anaerobic Digestion of Undiluted Simulant Human Excreta for Sanitation and Energy Recovery in Less-Developed Countries. Energy for Sustainable Development, 29, 57-64. https://doi.org/10.1016/j.esd.2015.09.005

[8] Kawanga, O.C. (2003) The Impact of Urbanization on Sanitary Conveyances and Sewage Treatment Facilities in the City of Lusaka, Zambia. International Symposium on Ecological Sanitation, Vol. 2, 927-933.

[9] Spuhler, D., Scheidegger, A. and Maurer, M. (2018) Generation of Sanitation System Options for Urban Planning Considering Novel Technologies. Water Research, 145, 259-278. https://doi.org/10.1016/j.watres.2018.08.021

[10] UNICEF Zambia (2016) Zambia Cholera Outbreak Report. UNICEF, Lusaka.

[11] Nyambe, S., Brunkard, J.M., Kapata, N. and Mazaba, L.M. (2018) Cholera Epidemic-Lusaka, Zambia, October 2017-May 2018. Centers for Disease Controls and Prevention, Lusaka.

[12] The World Bank (2012) Economic Impacts of Poor Sanitation in Africa. WSP.

[13] ERB (2018) Energy Regulations Board. http://www.erb.org.zm/content.php?viewpage=erips

[14] Lusakatimes (2015) Electricity Tariffs Increased with Effect from Midnight, Residential Customers Unaffected. lusakatimes.com, Lusaka.

[15] Lusakatimes (2017) ERB Approves ZESCO’s Application to Hike Electricity Tariffs by $75 \%$. Lusakatimes.com, Lusaka.

[16] Ministry of Energy (2018) Scaling-Up Renewable Energy Programmes (SRE) Investment Plan for Zambia, Government of Zambia. Ministry of Energy, Lusaka.

[17] Christof, R., Appleby, P., Fennema, J. and Alexa (2015) Economic Development and the Demand for Energy: A Historical Perspective on the Next 20 Years. 
[18] Zsirai, I. (2010) Sewage Sludge as Renewable Energy. Budapest.

[19] Balat, M. and Balat, H. (2009) Biogas as a Renewable Energy Source-A Review Energy Sources. Energy Sources, Part A: Recovery, Utilization, and Environmental Effects, 31, 1280-1293. https://doi.org/10.1080/15567030802089565

[20] Bachmann, N. (2015) Sustainable Biogas Production in Municipal Wastewater Treatment Plants. IEA Bioenergy, Paris.

[21] Center for Climate and Energy Solutions (2017) Climate Techbook. https://www.c2es.org/docUploads/AnaerobicDigesters.pdf

[22] Mang, H.-P. and Li, Z. (2010) Technological Review of Biogas Sanitation. GIZ, Eschborn.

[23] Laramee, J. and Davis, J. (2013) Economic and Environmental Impacts of Domestic Bio-Digesters: Evidence from Arusha, Tanzania. Energy for Sustainable Development, 17, 296-304. https://doi.org/10.1016/j.esd.2013.02.001

[24] Vasco-Correa, J., Manandhar, A. and Shah, A. (2018) Economic Implications of Anaerobic Digestion for Bioenergy Production and Waste Management. Ohio State University, Columbus.

[25] Teodorita, A.S., Rutz, D., Prassl, H. and Mi (2008) Biogas Handbook. University of Southern Denmark, Esbjerg.

[26] Sinicropi, P.J. (2012) American Biogas Council.

[27] Laramee, J., Tilmans, S. and Davis, J. (2017) Costs and Benefits of Biogas Recovery from Communal Anaerobic Digesters Treating Domestic Wastewater: Evidence from Peri-Urban Zambia. Journal of Environmental Management, 210, 23-35. https://doi.org/10.1016/j.jenvman.2017.12.064

[28] Cakir, F.Y. and Stenstrom, M.K. (2005) Greenhouse Gas Production: A Comparison between Aerobic and Anaerobic Wastewater Treatment Technology. 39th Edition, Elsevier, Amsterdam. https://doi.org/10.1016/j.watres.2005.07.042

[29] McCarty, P.L., Kim, J., Shin, C., Lee, P.-H. and Bae, J. (2015) Anaerobic Fluidized Bed Membrane Bioreactors for the Treatment of Domestic Wastewater. In: Anaerobic Biotechnology: Environmental Protection and Resource Recovery, World Scientific Publishing, Singapore, 211-237. https://doi.org/10.1142/9781783267910_0010

[30] Soto, M., Mendez, R. and Lema, J.M. (1993) Methanogenic and Non-Methanogenic Activity Tests-Theoretical Basis and Experimental Set-Up. Water Research, 27, 1361-1376. https://doi.org/10.1016/0043-1354(93)90224-6

[31] Central Statistics Office (2018) Zambia in Figures. Central Statistical Office Information, Research and Dissemination Division, Lusaka.

[32] LCC (2019) Interviewee, Areas of Livingstone.

[33] Myre, E. and Shaw, R. (2006) The Turbidity Tube: Simple and Accurate Measurement of Turbidity in the Field. Michigan Technology University, Houghton.

[34] ET Power Machinery Co. Ltd. (2020) Cummins 45 Kw Biogas Generator Set. http://engine-trade.com/product/cummins-45kw-biogas-generator-set.htm

[35] ERB Zambia (2015) Overview of the Energy Sector in Zambia: Case of Renewable Energy. ERB, Lusaka.

[36] Park, J.A., Hur, J.M., Son, B.S. and Lee, J.H. (2001) Effective Treatment of Night Soil Using Anaerobic Sequencing Batch Reactor (ASBR). Cheric, Seoul. https://doi.org/10.1007/BF02698295 